\title{
Phytoconstituents of the Gynura procumbens ethanol leaf extract and its fractions and their effects on viability of macrophages
}

\author{
Manimegalai Manogaran ${ }^{1}$, Vuanghao $\operatorname{Lim}^{2 \oplus}$, Rafeezul Mohamed ${ }^{* \oplus}$ \\ ${ }^{1}$ Regenarative Medicine Cluster, Advanced Medical and Dental Institute, Universiti Sains, Malaysia \\ ${ }^{2}$ Integrative Medicine Cluster, Advanced Medical and Dental Institute, Universiti Sains, Malaysia
}

\section{A R T I C LE I N F O}

Article Type:

Original Article

\section{Article History:}

Received: 20 December 2018

Accepted: 20 March 2019

\section{Keywords:}

Gynura procumbens

Liquid Chromatography-Mass

Spectrometry

Cell viability

RAW264.7 cells

\begin{abstract}
A B S T R A C T
Introduction: Gynura procumbens (GP) is a medicinal plant with numerous beneficial pharmacological activities. The aim of this study was to identify the bioactive phytoconstituents in GP ethanol extract and hexane, chloroform, ethyl acetate, and aqueous fractions of GP, and also to evaluate the cell viability of GP ethanol extract and its fractions-treated RAW264.7 cells. Methods: The ethanol GP leaf extract was prepared and further subjected to fractionation. The cell viability of GP ethanol extract and its fractions-treated RAW264.7 cells were measured by PrestoBlue. The phytoconstituents of GP ethanol extract and its fraction were determined by using liquid chromatography-mass spectrometry (LC-MS).

Results: RAW264.7 cells exposed to the GP ethanol extract and its fractions showed significantly high proliferation and weak cytotoxic effect on the macrophages, with an average inhibitory concentration of $90 \%$ at 24,48 , and 72 hours of incubation. However, at a concentration of 10 $\mu \mathrm{g} / \mathrm{mL}$, the aqueous GP fraction clearly displayed anti-proliferative properties because the cell viability of aqueous GP fraction-treated RAW264.7 cells reduced to $64 \%, 29 \%$ and $4 \%$ after 24 , 48 and 72 hours of incubation, respectively. The GP extracts and its fractions contained mainly fatty acids, flavonoids, sesquiterpenoids, and products of chlorophyll breakdown.

Conclusion: GP ethanol extract and its fractions at certain concentrations may act as immunomodulators, as they induced promising proliferation activity of macrophages. Further studies are needed to determine either the identified chemical compounds influenced on the proliferation of macrophages solely or cooperatively.
\end{abstract}

\section{Implication for health policy/practice/research/medical education:}

Gynura procumbens ethanol extract and its fractions contain compounds from group of fatty acids, flavonoids, sesquiterpenoids and product of chlorophyll breakdown which can act as immunodulators in regulating macrophage proliferation.

Please cite this paper as: Manogaran M, Lim V, Mohamed R. Phytoconstituents of the Gynura procumbens ethanol leaf extract and its fractions and their effects on viability of macrophages. J Herbmed Pharmacol. 2019;8(3):224-230. doi: 10.15171/ jhp.2019.33.

\section{Introduction}

Gynura procumbens (GP), a tropical plant that belongs to the family Asteraceae, is found extensively in Southeast Asia, particularly in Indonesia, Malaysia, and Thailand (1). GP reaches a height of $1-3 \mathrm{~m}$ and has fleshy stems and ovate-elliptical or lanceolate shaped leaves (2). In Malaysia, GP is known as Sambung nyawa, which means "prolongation of life" (3), and eating raw fresh leaves has been scientifically proven to be safe (4). GP traditionally is used to treat eruptive fever, kidney disease, migraines, constipation, hypertension, diabetes mellitus, and cancer (5). Intensive studies of GP have shown that it has anti- herpes simplex virus (6), anti-hyperglycaemic (7), antiinflammatory (8), anti-hyperlipidemic (9), and blood hypertension reduction (10) capabilities. These beneficial properties may be due to the active chemical constituents of GP, such as flavonoids, saponins, tannins, terpenoids, steroid glycosides, rutin, and kaempferol (7,10-12). Almost $75 \%$ of plant-based therapeutic drugs used worldwide originally are traditional-based medicines (13), and there is growing interest in discovering herbal medicines for management of various diseases. Therefore, the safety and potential toxicity of medical plants and edible materials must be determined (5). 
Macrophages are scavenger cells that play an important role in regulating inflammatory responses by destroying viruses, bacteria, and parasites via phagocytosis process (14). In addition, macrophages also remove apoptotic cells in inflamed tissues (14). When macrophages ingested particles or any foreign agent, they trigger secretion of pro-inflammatory cytokines such as Interleukin-1 beta (IL-1 $\beta$ ), IL-6, IL-12 and tumor necrosis factor alpha $(\mathrm{TNF}-\alpha)$. It also can produce anti-inflammatory cytokines such as IL-10 and tumor growth factor beta (TGF- $\beta$ ) (14). However, the ingestion of apoptotic cells does not stimulate its activation (15). Few studies of the bioactive constituents of GP extracts and their effects on phagocytic cells (i.e., macrophages) have been conducted. The current study was carried out to identify the bioactive secondary metabolites that may influence the cell viability of mouse murine macrophage cells (RAW 264.7) treated with GP ethanol extract and its fractions.

\section{Materials and Methods}

Plant material

Fresh leaves of GP were purchased from Herbagus Sdn. Bhd. at Kepala Batas, Penang, Malaysia and identified by a botanist from the Herbarium, School of Biological Sciences, Universiti Sains Malaysia. The plant was identified as GP and the voucher number was recorded as USM Herbarium 11753.

\section{Preparation of GP leaf extract}

Fresh GP leaves were washed with water to remove dirt prior to drying at $40^{\circ} \mathrm{C}$ for a week. The dried leaves were pulverized using a herb grinder. The leaf powder was extracted repeatedly for 3 days with ethanol (97\%) (Thermo Fisher, San Diego, CA, USA) using the maceration method at a ratio of 1:10 raw materials to solvent. Macerated raw material was stirred occasionally and fresh ethanol was replenished every 3 days for 9 days. The extract was filtered through filter paper (Whatman No.1), and the filtrate was concentrated using a rotary evaporator at $45^{\circ} \mathrm{C}$. The concentrated extract was lyophilized to obtain the dry powdered extract. The ethanol leaf extract was stored at $-20^{\circ} \mathrm{C}$ until further use.

\section{Fractionation}

The ethanol GP leaf extract was subjected to fractionation. First, $20 \mathrm{~g}$ of the powdered extract was reconstituted in distilled water for liquid-liquid partition with an equal volume of $n$-hexane ( $200 \mathrm{~mL} \times 3$ times) in a separating funnel. The separating funnel was shaken gently, and the $n$-hexane portion was collected. Subsequently, the residue was partitioned with solvents of increasing polarity (chloroform, ethyl acetate, and aqueous). The fractions were concentrated using a rotary evaporator at $45^{\circ} \mathrm{C}$ and freeze dried to obtain dried fractionated extracts. The fractions were stored at $-20^{\circ} \mathrm{C}$ until further use.
Cell viability assay

RAW 264.7 cells were cultured in Dulbecco's Modified Eagle Medium (DMEM) supplemented with $10 \%$ fetal bovine serum, $1 \%$ antibiotics $(250 \mathrm{U} / \mathrm{mL}$ penicillin, $250 \mu \mathrm{g} / \mathrm{mL}$ streptomycin), and 1\% HEPES 1M. The cells were maintained at $37^{\circ} \mathrm{C}$ in a humidified incubator set at $5 \% \mathrm{CO}_{2}$. The cells were seeded at a concentration of 1 $\times 10^{4}$ cells $/ \mathrm{mL}$ in 96 -well plates and incubated at $37^{\circ} \mathrm{C}$ at $5 \% \mathrm{CO}_{2}$ for 24 hours. After $24 \mathrm{~h}$ of incubation, the cells were treated with the GP ethanol extract and its fractions (hexane, chloroform, ethyl acetate, and aqueous) at concentrations ranging between 1 to $100 \mu \mathrm{g} / \mathrm{mL}$ and 0.01 to $10 \mu \mathrm{g} / \mathrm{mL}$, respectively. The plates were incubated at $37^{\circ} \mathrm{C}$ at $5 \% \mathrm{CO}_{2}$ for 24,48 , and $72 \mathrm{~h}$. After each respective time of incubation, the medium was removed and $10 \mu \mathrm{L}$ of PrestoBlue (PB) reagent (Invitrogen, Carlsbad, CA, USA) and $90 \mu \mathrm{L}$ of fresh medium were added to each well, and the plates were further incubated for 50 minutes. The fluorescence of the color complex was read at 544-590 $\mathrm{nm}$ using a FLUOstar ${ }^{\circledR}$ Omega microplate reader (BMG LABTECH, Ortenberg, Germany).

Liquid chromatography- mass spectrometry analysis of the GP ethanol extract and its fractions

The GP ethanol extract and its fractions were dissolved in ethanol, with the exception of the aqueous fraction, which was dissolved in distilled water (50\%) and ethanol (50\%). The samples were centrifuged at 14000 RPM for 15 minutes, filtered through a $0.45 \mu \mathrm{m}$ nylon syringe filter, and diluted 10x for analysis. liquid chromatography-mass spectrometry (LC-MS) analysis was performed using an Agilent 1290 Infinity LC system coupled to an Agilent 6520 Accurate-Mass Q-TOF mass spectrometer with a dual ESI source (Santa Clara, CA, USA). Separation was performed using an Agilent Zorbax Eclipse XDB-C18, Narrow-Bore column $(2.1 \mathrm{~mm}$ x $150 \mathrm{~mm}$ x $3.5 \mu \mathrm{m})$. The column temperature was $25^{\circ} \mathrm{C}$, and the auto sampler temperature was programmed at $4^{\circ} \mathrm{C}$. The mobile phases were $0.1 \%$ formic acid in water and $0.1 \%$ formic acid in acetonitrile at a flow rate of $0.5 \mathrm{~mL} / \mathrm{min}$. Aliquot samples of $1 \mu \mathrm{L}$ and $2 \mu \mathrm{L}$ were injected for targeted MS and MS/MS positive and negative modes, respectively. The chromatographic data were processed using Agilent MassHunter Qualitative Analysis software. The identified compounds were verified by comparing with the METLIN metabolomic database.

\section{Statistical analysis}

The cell viability results were expressed as mean \pm standard error mean (SEM). One-way ANOVA was applied to determine significance between the untreated group vs. treated groups. Analysis was performed by Statistical Package for the Social Sciences (SPSS) software version 19.0 , and differences were considered significance at $P<0.05$. The experiment was performed three times. 


\section{Results}

The GP ethanol extract and its fractions promote proliferation of RAW264.7 cells

The GP ethanol extract and its hexane, chloroform, ethyl acetate, and aqueous fractions stimulated proliferation of RAW264.7 cells, as the percentages of cell viability were above $100 \%$ compared to untreated cells. In addition, these extracts had a weak cytotoxic effect on the cells, with an average inhibitory concentration of $90 \%$ at 24,48 , and 72 $\mathrm{h}$ of incubation (Figure 1A-E). However, cell proliferation decreased as extract and fractions concentration, and also time increased (Figure $1 \mathrm{~A}-\mathrm{E}$ ). At $10 \mu \mathrm{g} / \mathrm{mL}$, the aqueous GP fraction clearly displayed anti-proliferative properties because the cell viability of aqueous GP fraction-treated RAW264.7 cell reduced to $64 \%, 29 \%$ and $4 \%$ after 24,48 and 72 hours of incubation, respectively (Figure 1B).

Phytoconstituents identified in the GP ethanol extract and its fractions

The bioactive constituents present in the GP ethanol extract and its fractions were successfully identified using LC-MS. Figure 2 shows the MS chromatograms for positive and negative modes of the GP ethanol extract. Figure 3 displays the MS chromatograms for positive and negative modes of the GP aqueous fraction. Figure 4 shows the MS chromatograms for positive and negative modes of the GP ethanol chloroform fraction. Figure 5 demonstrates the MS chromatograms for positive and negative modes of the GP ethyl acetate fraction. Figure 6 shows the MS chromatograms for positive and negative modes of the GP hexane fraction. LC-MS revealed different types of bioactive phytochemicals with high and low molecular weights in varying quantities present in positive and negative modes of GP ethanol extract and its fractions. The identified compounds of $\alpha-9(10)-$ EpODE, Cpd 45: 9Z,12Z,15E-octadecatrienoic acid, 6E,9E-octadecadienoic acid and Pheophorbide a are presented in both positive and negative modes of GP ethanol extract (Table 1). Table 2 listed compounds of Isovitexin 2"-O-xyloside, Homoesperetin 7-rutinoside, 9Z,12Z,15E-octadecatrienoic acid, Ipolamiide and 6,8-Di-C-beta-D-arabinopyranosylapigenin found in both positive and negative modes of GP aqueous fraction. Table 3 shows the compounds that present in both positive and negative modes of GP chloroform fraction namely 4-(2-hydroxypropoxy)-3,5-dimethyl-Phenol, 11-hydroperoxy-12,13-epoxy-9-octadecenoic acid, decenedioic acid, (-)-12-hydroxy-9,10-dihydrojasmonic
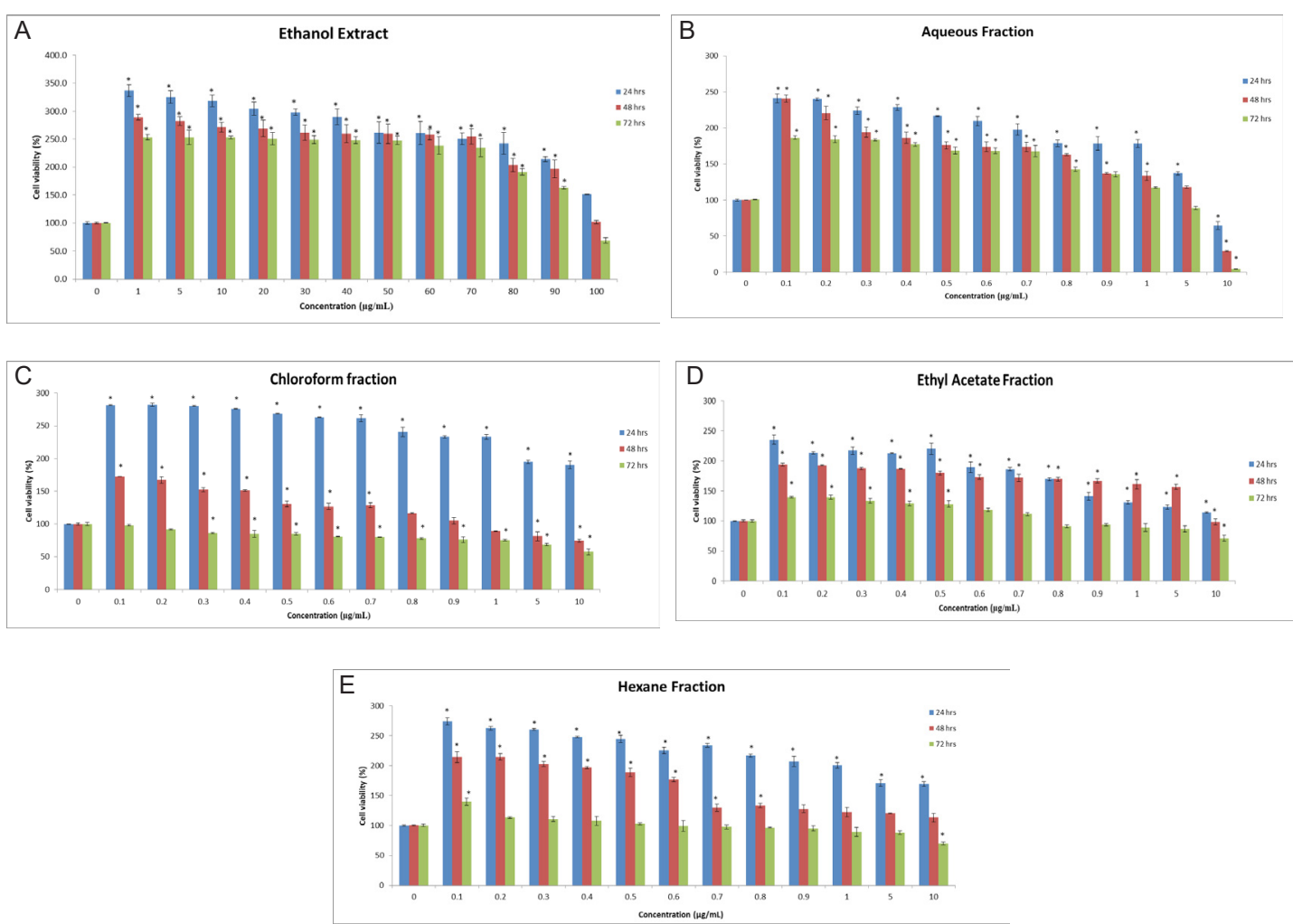

Figure 1. Cell viability of RAW264.7 cells treated with the Gynura procumbens (GP) ethanol extract and its fractions at 24,48 , and $72 \mathrm{~h}$. The GP ethanol extract and the aqueous, chloroform, ethyl acetate, and hexane fractions induced proliferation of RAW264.7 cells (A-E), but proliferation decreased with increasing extract concentration and time $(A-E)$. At $10 \mu \mathrm{g} / \mathrm{mL}$, the aqueous GP fraction clearly displayed anti-proliferative effect because the cell viability of aqueous GP fraction-treated RAW264.7 cell reduced to $64 \%, 29 \%$ and $4 \%$ after 24,48 and $72 \mathrm{~h}$ of incubation, respectively (B). The cell viability results (in percentages) were compared between the untreated group vs. treated groups $\left({ }^{*} P<0.05\right)$. The values represent the mean \pm SEM. The experiment was performed three times. 

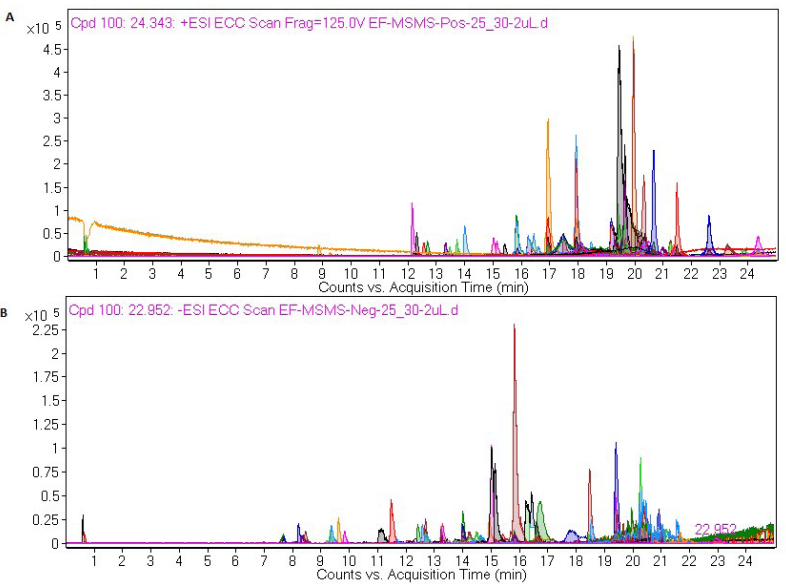

Figure 2. Ion chromatograms for positive $(A)$ and negative $(B)$ modes of $G$. procumbens ethanol extract.

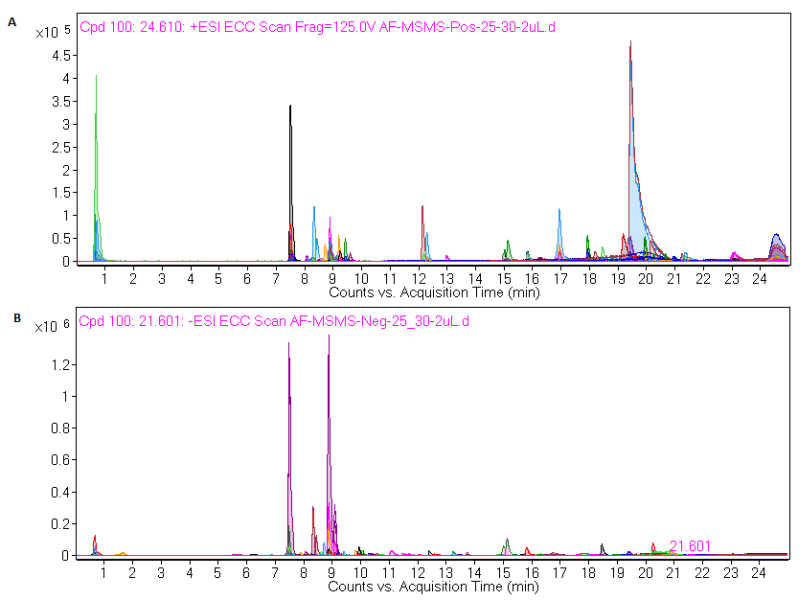

Figure 3. Ion chromatograms for positive (A) and negative (B) modes of $G$. procumbens aqueous fraction.

acid, 5,8,12-trihydroxy-9-octadecenoic acid and (6S)dehydrovomifoliol. Compounds of p-salicylic acid (4-hydroxybenzoic acid), luteolin 7-rhamnosyl (1->6) galactoside, 6-hydroxyluteolin 5-rhamnoside, 2,3-dinor Thromboxane B1 and Formononetin 7-O-glucoside-6"$\mathrm{O}$-malonate were found in positive and negative modes of GP ethyl acetate fraction (Table 4). Table 5 listed compounds of harderoporphyrin, 6E,9E-octadecadienoic acid, pheophorbide a and 9Z,12Z,15E-octadecatrienoic acid detected in positive and negative modes of GP hexane fraction. Among them, 9Z, 12Z, 15E-octadecatrienoic acid was present in the GP ethanol extract as well as the hexane and aqueous fractions. In addition, $6 \mathrm{E}$, 9E-octadecadienoic acid and pheophorbide $\mathrm{A}(\mathrm{Pa})$ were present in both the GP ethanol extract and the hexane fraction.

\section{Discussion}

Treatment of murine macrophages (RAW264.7) with the GP ethanol extract and its fractions may impact cell morphology, growth, death, and disintegration. In this
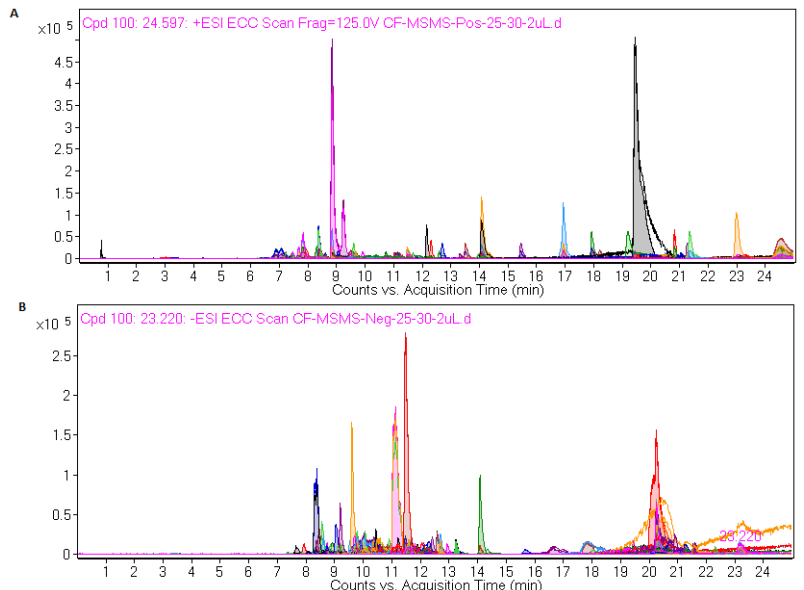

Figure 4. Ion chromatograms for positive $(A)$ and negative $(B)$ modes of $G$. procumbens chloroform fraction.

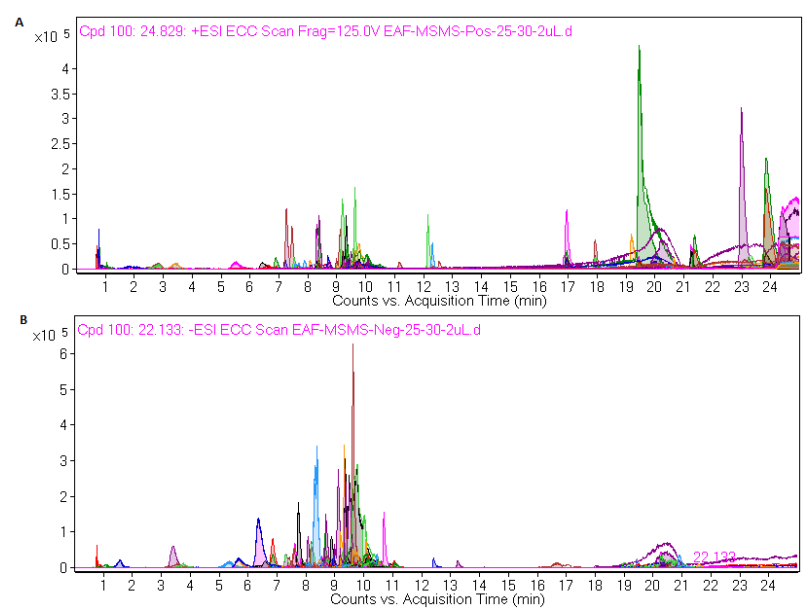

Figure 5. Ion chromatograms for positive $(A)$ and negative $(B)$ modes of $G$. procumbens ethyl acetate fraction.

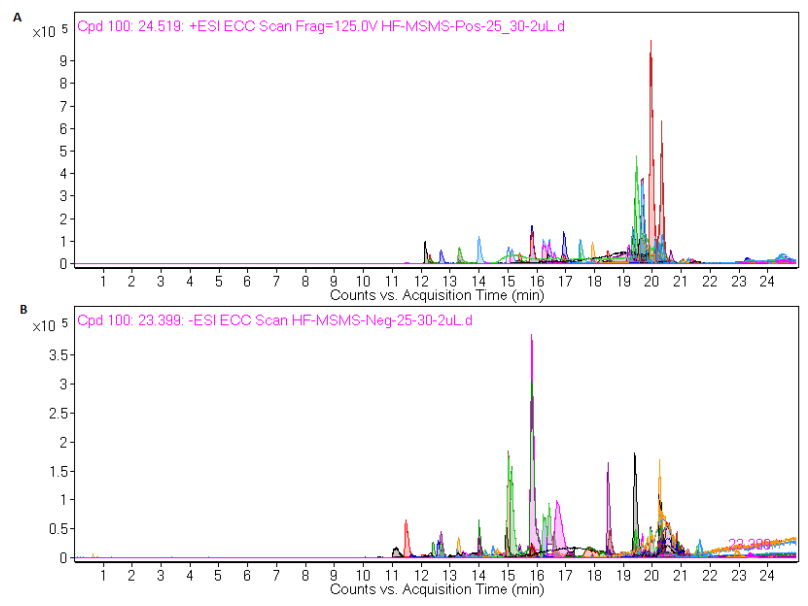

Figure 6. Ion chromatograms for positive (A) and negative (B) modes of $G$. procumbens hexane fraction.

study, cell viability of treated cells was monitored using $\mathrm{PB}$, which is a resazurin-based reagent that acts as a signal for mitochondrial metabolic activity (15). PB solution is 
Table 1. Compounds identified in G. procumbens ethanol extract (positive and negative ion modes) using LC-MS

\begin{tabular}{lccl}
\hline Compound & Formula & $\mathrm{M} / \mathrm{Z}$ & Group \\
\hline$\alpha-9(10)$-EpODE & $\mathrm{C}_{18} \mathrm{H}_{30} \mathrm{O}_{3}$ & 293.212 & Fatty acid \\
Cpd 45: 9Z,12Z,15E-octadecatrienoic acid & $\mathrm{C}_{18} \mathrm{H}_{30} \mathrm{O}_{2}$ & 277.2169 & Fatty acid (linolenic acid) \\
6E,9E-octadecadienoic acid & $\mathrm{C}_{18} \mathrm{H}_{32} \mathrm{O}_{2}$ & 279.2329 & Fatty acyls \\
Pheophorbide a & $\mathrm{C}_{35} \mathrm{H}_{36} \mathrm{~N}_{4} \mathrm{O}_{5}$ & 593.277 & Product of chlorophyll breakdown \\
\hline
\end{tabular}

Table 2. Compounds identified in the G. procumbens aqueous fraction (positive and negative ion modes) using LC-MS

\begin{tabular}{llll}
\hline Compound & Formula & M/Z & Group \\
\hline Isovitexin 2"-O-xyloside & $\mathrm{C}_{26} \mathrm{H}_{28} \mathrm{O}_{14}$ & 565.1563 & Flavonoid \\
Homoesperetin 7-rutinoside & $\mathrm{C}_{29} \mathrm{H}_{36} \mathrm{O}_{15}$ & 642.2401 & Flavanone glycoside \\
$9 Z, 12 Z, 15 E-$-octadecatrienoic acid & $\mathrm{C}_{18} \mathrm{H}_{30} \mathrm{O}_{2}$ & 279.2321 & Fatty acid (linolenic acid) \\
Ipolamiide & $\mathrm{C}_{17} \mathrm{H}_{26} \mathrm{O}_{11}$ & 424.1822 & Terpene glycoside \\
6,8-Di-C-beta-D-arabinopyranosylapigenin & $\mathrm{C}_{25} \mathrm{H}_{26} \mathrm{O}_{13}$ & 533.1297 & Flavonoid \\
\hline
\end{tabular}

Table 3. Compounds identified in G. procumbens chloroform fraction (positive and negative ion modes) using LC-MS

\begin{tabular}{llll}
\hline Compound & Formula & $\mathrm{M} / \mathrm{Z}$ & Group \\
\hline 4-(2-hydroxypropoxy)-3,5-dimethyl-Phenol & $\mathrm{C}_{11} \mathrm{H}_{16} \mathrm{O}_{3}$ & 197.1173 & Phenolic \\
11-hydroperoxy-12,13-epoxy-9-octadecenoic acid & $\mathrm{C}_{18} \mathrm{H}_{32} \mathrm{O}_{5}$ & 346.259 & Octadecanoids \\
Decenedioic acid & $\mathrm{C}_{10} \mathrm{H}_{16} \mathrm{O}_{4}$ & 218.1384 & Unsaturated fatty acid \\
(-)-12-hydroxy-9,10-dihydrojasmonic acid & $\mathrm{C}_{12} \mathrm{H}_{20} \mathrm{O}_{4}$ & 227.1285 & Oxo monocarboxylic acid \\
5,8,12-trihydroxy-9-octadecenoic acid & $\mathrm{C}_{18} \mathrm{H}_{34} \mathrm{O}_{5}$ & 329.2329 & Hydroxy fatty acid \\
(6S)-dehydrovomifoliol & $\mathrm{C}_{13} \mathrm{H}_{18} \mathrm{O}_{3}$ & 223.1327 & Sesquiterpenoids (terpenes) \\
\hline
\end{tabular}

Table 4. Compounds identified in G. procumbens ethyl acetate fraction (positive and negative ion modes) using LC-MS

\begin{tabular}{llll}
\hline Compound & Formula & $\mathrm{M} / \mathrm{Z}$ & Group \\
\hline p-Salicylic acid (4-Hydroxybenzoic acid) & $\mathrm{C}_{7} \mathrm{H}_{6} \mathrm{O}_{3}$ & 139.0389 & Monohydroxybenzoic acid \\
Luteolin 7-rhamnosyl(1->6)galactoside & $\mathrm{C}_{27} \mathrm{H}_{30} \mathrm{O}_{15}$ & Trihydroxyflavone \\
6-Hydroxyluteolin 5-rhamnoside & $\mathrm{C}_{21} \mathrm{H}_{20} \mathrm{O}_{11}$ & 595.1664 & Hydroxycinnamic acid \\
2,3-dinor Thromboxane B1 & $\mathrm{C}_{18} \mathrm{H}_{32} \mathrm{O}_{6}$ & 449.1084 & Fatty Acyls \\
Formononetin 7-O-glucoside-6"-O-malonate & $\mathrm{C}_{25} \mathrm{H}_{24} \mathrm{O}_{12}$ & 362.2541 & Glycoisoflavonoids \\
\hline
\end{tabular}

Table 5. Compounds identified in G. procumbens hexane fraction (positive and negative ion modes) using LC-MS

\begin{tabular}{llll}
\hline Compound & Formula & $\mathrm{M} / \mathrm{Z}$ & Group \\
\hline Harderoporphyrin & $\mathrm{C}_{35} \mathrm{H}_{36} \mathrm{~N}_{4} \mathrm{O}_{6}$ & 609.2718 & Porphyrins \\
6E,9E-octadecadienoic acid & $\mathrm{C}_{18} \mathrm{H}_{32} \mathrm{O}_{2}$ & 279.2329 & Fatty Acyls \\
Pheophorbide a & $\mathrm{C}_{35} \mathrm{H}_{36} \mathrm{~N}_{4} \mathrm{O}_{5}$ & 593.277 & Product of chlorophyll breakdown \\
$92,12 Z, 15 E$-octadecatrienoic acid & $\mathrm{C}_{18} \mathrm{H}_{30} \mathrm{O}_{2}$ & 279.2321 & Fatty acid (Linolenic acid) \\
\hline
\end{tabular}

water soluble and non-toxic to the cells, so it is useful for monitoring toxicity of the treatment to the cells in vitro (15). PB is the fastest known live assay, as the incubation period is only 10 minutes (15). Changes in cell viability also can be revealed calorimetrically or fluorometrically (15). Results of the present study showed that treatment with the GP ethanol extract and its fractions stimulated proliferation of RAW264.7 cells but the cell proliferation decreased in a concentration- and time-dependent manner. The effect of the GP ethanol extract, but not the fractions, on immune cells was reported previously. Results of the current study were in agreement with those of a previous study that suggested that the GP ethanol extract stimulates macrophages to clear carbon particles in 
the animal bloodstream (16). Our findings also are in line with results of a recent study of the immunomodulatory activity of the GP ethanol leaf extract on mice splenic cells (17). In that study, treatment with the GP extract at 0.1 and $1.0 \mu \mathrm{g} / \mathrm{mL}$ promoted greater proliferation of $\mathrm{CD} 4+\mathrm{CD} 25+$, CD4+CD62L-, CD4+CD62L+, CD8+CD62L-, andCD8+CD62L $+\mathrm{T}$ cells but reduced proliferation of B220+ cells (17), whereas the $10 \mu \mathrm{g} / \mathrm{mL}$ dose enhanced the proliferation of B cells (17). Furthermore, Sriwanthana et al (18) also found that in humans, the GP extract accelerated lymphocyte stimulation, which suggests that GP is a putative immunostimulant. In the current study, the aqueous fraction at concentration of $10 \mu \mathrm{g} /$ $\mathrm{mL}$ clearly displayed anti-proliferative properties. These results were supported by Lee et al (19) who reported an anti-proliferative effect of the aqueous extract of GP, as it inhibited mesangial cell proliferation via suppression of PDGF-BB and TGF- $\beta$ expression and modulation of CDK1 and CDK2 expression.

On the other hand, LC-MS was used to identify the bioactive constituents that might be involved in the stimulation of RAW264.7 cells proliferation. Many compounds in the GP ethanol extract and its fractions were identified, and some distinctive bioactive compounds were present in both positive and negative ion modes, such as flavonoids, fatty acids, octadecanoids, porphyrins, sesquiterpenoids (terpenes), a product of chlorophyll breakdown (Pa), trihydroxyflavone, monohydroxybenzoic acid, and hyroxycinnamic acid. 9Z, $12 \mathrm{Z}, 15 \mathrm{E}$-octadecatrienoic acid from the fatty acid group (linolenic acid) was present in the GP ethanol extract and the hexane and aqueous fractions. This compound may be responsible for inducing proliferation of RAW264.7 cells, as suggested by Ohue-Kitano et al (20). They studied the effect of $\alpha$-linolenic acid (ALA) and its gut lactic acid bacteria metabolites 13-hydroxy-9(Z), 15(Z)octadecadienoic acid (13-OH) and 13-oxo-9(Z),15(Z)octadecadienoic acid (13-oxo) on the differentiation of M2 macrophages from bone marrow-derived cells (BMDCs) (20). They showed that treatment of BMDCs with ALA, 13-OH, or 13-oxo in the presence of IL- 4 or IL-13 for $24 \mathrm{~h}$ induced the expression M2 macrophage markers CD206 and arginase-1 (20). In an in vivo experiment, they also demonstrated high deposition of M2 macrophages in the lamina propria of the small intestine of $\mathrm{C} 57 \mathrm{BL} / 6$ mice treated intragastrically with ALA, 13-OH, or 13-oxo at 1 $\mathrm{g} / \mathrm{kg}$ of body weight per day for 3 days (20).

In the current study, 6E, 9E-octadecadienoic acid and (Pa) were identified in both the GP ethanol extract and the hexane fraction. 6E, 9E-octadecadienoic acid may have an effect similar to that of $9 \mathrm{Z}, 12 \mathrm{Z}, 15 \mathrm{E}$-octadecatrienoic acid, as they are in the same fatty acid group (linoleic acid). $\mathrm{Pa}$ is a product of chlorophyll breakdown (21), and it may be a potential photosensitizer for photodynamic therapy of human cancer (22). Bui-Xuan et al (22) also reported that Pa promoted the growth of RAW 264.7 cells, with maximum effect at $1.0 \mu \mathrm{M}$ after 24,48 , and $72 \mathrm{~h}$ of treatment.

\section{Conclusion}

The GP ethanol extract and its fractions at certain concentrations may act as potential immunomodulators, as they stimulated macrophage proliferation instead of cell death. This premise was further strengthened by identification of compounds such as linoleic acid and a product of chlorophyll breakdown in the extracts, which previously were shown to promote macrophage proliferation (20,22). Diverse biologically active constituents in the GP ethanol extract and its fractions warrant further study to determine their biological and pharmacological properties.

\section{Acknowledgement}

This paper was a part of $\mathrm{PhD}$ thesis of Manimegalai Manogaran. The authors would like to acknowledge the Ministry of Education, Malaysia for awarding Fundamental Research Grant Scheme (FRGS), No. 203/ CIPPT/6711507 to fund this research.

\section{Author contributions}

MM carried out the experiment. LV and RM designed the research workflow. RM was principal investigator of FGRS grants which funded this project and wrote the manuscripts. All read and confirmed the final version of submitted manuscript for publication.

\section{Conflict of interests}

The authors declare no conflict of interest.

\section{Ethical consideration}

All ethical issues such as plagiarism, misconduct, data fabrication, double publication and submission redundancy have been completely checked by the authors.

\section{Funding/Support}

This research was funded by Fundamental Research Grant Scheme (FRGS), No. 203/CIPPT/6711507, Ministry of Education, Malaysia.

\section{References}

1. Mou KM, Dash PR. A comprehensive review on Gynura procumbens leaves. Int J Pharmacogn. 2016;3(4):167-74.

2. Rahman AFMM, Asad MSA. Chemical and biological investigations of the leaves of Gynura procumbens. Int J Biosci. 2013;3(4):36-43.

3. Bodeker G, Salleh H, Shekar SC. Health and Beauty from the Rainforest: Malaysian Traditions of Ramuan. Kuala Lumpur: Editions Didier Millet Pty Ltd; 2009.

4. Rosidah, Yam MF, Sadikun A, Asmawi MZ. Antioxidant potential of Gynura procumbens. Pharm Biol. 2008;46(9):616-25. doi: 10.1080/13880200802179642. 
5. Rosidah, Yam MF, Sadikun A, Ahmad M, Akowuah GA, Asmawi MZ. Toxicology evaluation of standardized methanol extract of Gynura procumbens. J Ethnopharmacol. 2009;123(2):244-9. doi: 10.1016/j.jep.2009.03.011.

6. Nawawi A, Nakamura N, Hattori M, Kurokawa M, Shiraki K. Inhibitory effects of Indonesian medicinal plants on the infection of herpes simplex virus type 1 . Phytother Res. 1999;13(1):37-41. doi: 10.1002/(sici)10991573(199902)13:1<37::aid-ptr382>3.0.co;2-s.

7. Akowuah GA, Sadikun A, Mariam A. Flavonoid identification and hypoglycaemic studies of the butanol fraction from Gynura procumbens. Pharm Biol. 2002;40(6):405-10. doi: 10.1076/phbi.40.6.405.8440.

8. Iskander MN, Song Y, Coupar IM, Jiratchariyakul W. Antiinflammatory screening of the medicinal plant Gynura procumbens. Plant Foods Hum Nutr. 2002;57(3-4):233-44.

9. Zhang XF, Tan BK. Effects of an ethanolic extract of Gynura procumbens on serum glucose, cholesterol and triglyceride levels in normal and streptozotocin-induced diabetic rats. Singapore Med J. 2000;41(1):9-13.

10. Lam SK, Idris A, Abu Bakar Z, Ismail R. Gynura procumbens and blood pressure in the rat: a preliminary study. Asia Pac J Pharmacol. 1998;13(Suppl 1):14-15

11. Zahra AA, Kadir FA, Mahmood AA, Al Hadi AA, Suzy SM, Sabri SZ, et al. Acute toxicity study and wound healing potential of Gynura procumbens leaf extract in rats. J Med Plant Res. 2011;5(12):2551-8. doi: 10.5897/JMPR.

12. Kaewseejan N, Puangpronpitag D, Nakornriab $M$. Evaluation of phytochemical composition and antibacterial property of Gynura procumbens extract. Asian J Plant Sci. 2012;11(2):77-82. doi: 10.3923/ajps.2012.77.82.

13. Sen S, Chakraborty R. Revival, modernization and integration of Indian traditional herbal medicine in clinical practice: Importance, challenges and future. J Tradit Complement Med. 2017;7(2):234-44. doi: 10.1016/j. jtcme.2016.05.006.

14. Duffield JS. The inflammatory macrophage: a story of Jekyll and Hyde. Clin Sci (Lond). 2003;104(1):27-38.
15. Boncler M, Rozalski M, Krajewska U, Podsedek A, Watala C. Comparison of PrestoBlue and MTT assays of cellular viability in the assessment of anti-proliferative effects of plant extracts on human endothelial cells. J Pharmacol Toxicol Methods. 2014;69(1):9-16. doi: 10.1016/j. vascn.2013.09.003.

16. Yusoff WSYW, Saufi Johari A, Kamaruddin E, Mastuki MF, Abu MN, Safarudin Z. Effect of ethanol extracts of Gynura procumbens on in vivo phagocytosis of Wistar albino rats. J Teknol. 2016;78(6-7):95-9. doi: 10.11113/jt.v78.9090.

17. Dwijayanti DR, Rifa'i M. Gynura procumbens ethanolic extract promotes lymphocyte activation and regulatory $\mathrm{T}$ cell generation in vitro. J Trop Life Sci. 2015;5(1):14-9.

18. Sriwanthana B, Treesangsri W, Boriboontrakul B, Niumsakul S, Chavalittumrong P. In vitro effects of Thai medicinal plants on human lymphocyte activity. Songklanakarin J Sci Technol. 2007;29(Suppl 1):17-28.

19. Lee HJ, Lee BC, Chung JH, Wiryowidagdo S, Chun W, Kim SS, et al. Inhibitory effects of an aqueous extract of Gynura procumbens on human mesangial cell proliferation. Korean J Physiol Pharmacol. 2007;11(4):145-48.

20. Ohue-Kitano R, Yasuoka Y, Goto T, Kitamura N, Park SB, Kishino S, et al. alpha-Linolenic acid-derived metabolites from gut lactic acid bacteria induce differentiation of antiinflammatory M2 macrophages through G protein-coupled receptor 40. FASEB J. 2018;32(1):304-18. doi: 10.1096/ fj.201700273R.

21. Juan M, Minhu C, Yun D, Liang Q. Enhancing the efficacy of photodynamic therapy by a Chinese herbal medicine for hepatocellular carcinoma. Cancer Biol Ther. 2006;5(9):1117-9.

22. Bui-Xuan NH, Tang PM, Wong CK, Chan JY, Cheung KK, Jiang JL, et al. Pheophorbide a: a photosensitizer with immunostimulating activities on mouse macrophage RAW 264.7 cells in the absence of irradiation. Cell Immunol. 2011;269(1):60-7. doi: 10.1016/j.cellimm.2011.02.010. 